Science, Technology and Development 34 (1): 60-65, 2015

ISSN 0254-6418 / DOI: 10.3923/std.2015.60.65

(C) 2015 Pakistan Council for Science and Technology

\title{
Launching/Disappearance of Stone Apron, Block Floor Downstream of the Taunsa Barrage and Unprecedent Drift of the River towards Kot Addu Town
}

\author{
${ }^{1}$ Chaudary Zulfiqar Ali and ${ }^{2}$ Sarwar Muhammad Kaleem \\ ${ }^{1}$ Department of Civil Engineering, University of Engineering and Technology, \\ G.T. Road, Lahore, 54890, Pakistan \\ ${ }^{2}$ Centre of Excellence in Water Resources Engineering, University of Engineering and Technology, \\ G.T. Road, Lahore, 54890, Pakistan
}

\begin{abstract}
Taunsa barrage located on the Indus River, Pakistan was remodeled/rehabilitated and modernized in year 2005-08, spending more than eleven billion rupees borrowed from the World Bank. Major changes were made in its energy dissipation system/stilling basin and $7 \mathrm{ft}$ high sub-weir/wall was constructed at $800 \mathrm{ft}$ distance downstream of the barrage. The barrage showed poor performance during 2010 floods which caused an uncontrolled breach in its left marginal bund. The sounding and probing data of years 2010-14 showed the development of deep scour pits downstream of the barrage stilling basin and the situation at present is horrifying. The whole stone apron has been washed away, whereas, the concrete block floor along with inverted filters partially or completely disappeared. Moreover, the has river changed its route about 2.5-3.0 km towards Kot Addu, indicating regulation of flow with gates has vanished as the sub-weir is developing uniform flow on the downstream. This study investigates the performance of energy dissipation system in pre and post remodeled scenarios of the barrage and causes for extraordinary drift of the river towards Kot Addu. This research works concludes that remodeling of stilling basin is not rational and is the cause of launching of stone apron and block floor along with inverted filters. Further, construction of sub weir downstream of barrage is responsible for the drift of Indus River towards Kot Addu town.
\end{abstract}

Key words: Energy dissipation system, indus river, rehabilitation, stilling basin, sub-weir

\section{INTRODUCTION}

Taunsa Barrage was designed and constructed in year 1958. Taunsa barrage consists of 53 bays and 11 bays for weir and undersluices sections of the barrage, respectively. The clear waterway of the barrage is $3860 \mathrm{ft}$, whereas the width between abutments is $4346 \mathrm{ft}$. Two divide walls separate main weir and undersluices sections of the barrage. Each undersluice consists of $22 \mathrm{ft}$ wide navigation bay and silt excluder. The barrage was designed for a discharge of 1,000,000 cusec; but a super flood of above 1,260,000 cusecs could be passed through the barrage (PID., 2007).

A Jump type stilling basin along with auxiliary devices consisting of two rows of baffle blocks and two rows of friction blocks were provided to dissipate excessive kinetic energy. Such auxiliary devices enhance turbulence, kill rollers and stabilize hydraulic jump even if tail water depth becomes less. Almost all the barrages in Pakistan and India and elsewhere in the world are provided with similar auxiliary devices in the stilling basins (Chaudhary, 2009b).

Soon after the construction of Taunsa barrage, some of the baffles blocks were up-routed, which were reconstructed later on. Such damages were occurred repeatedly, showed structural flaws in baffle block foundation (Chaudhary, 2009b).

Since last 47 years, except uprooting of baffles blocks, the barrage functioned well with nominal replenishment of stone apron and annual repair/maintenance.

In year 2004, Punjab Irrigation Department with the assistance of foreign financial aid initiated a mega project to rehabilitate and modernize its barrages and irrigation infrastructure. Taunsa Barrage was remodeled/rehabilitated (year 2005-08) on emergency basis with the expense of more than 11 billion rupees. Major changes in barrage stilling basin were made by replacing baffle and friction blocks with chute blocks and sill wall (PID., 2004; Chaudhary, 2009a, 2010a, b). The $2 \mathrm{ft}$ top layer of stilling basin was replaced by $3 \mathrm{ft}$ thick reinforced concrete of $4000 \mathrm{psi}$. A $7 \mathrm{ft}$ high sub-weir/wall was also constructed at $900 \mathrm{ft}$ distance downstream of the barrage (Fig. 1). In under-sluices sections the crest level of the barrage and sub-weir are at RL 425 and RL 424, respectively. Whereas, in main weir section the crest level of barrage is at RL 428 and the sub-weir is at RL 424 (Fig. 1). 
Sci. Technol. Dev., 34 (1): 60-65, 2015

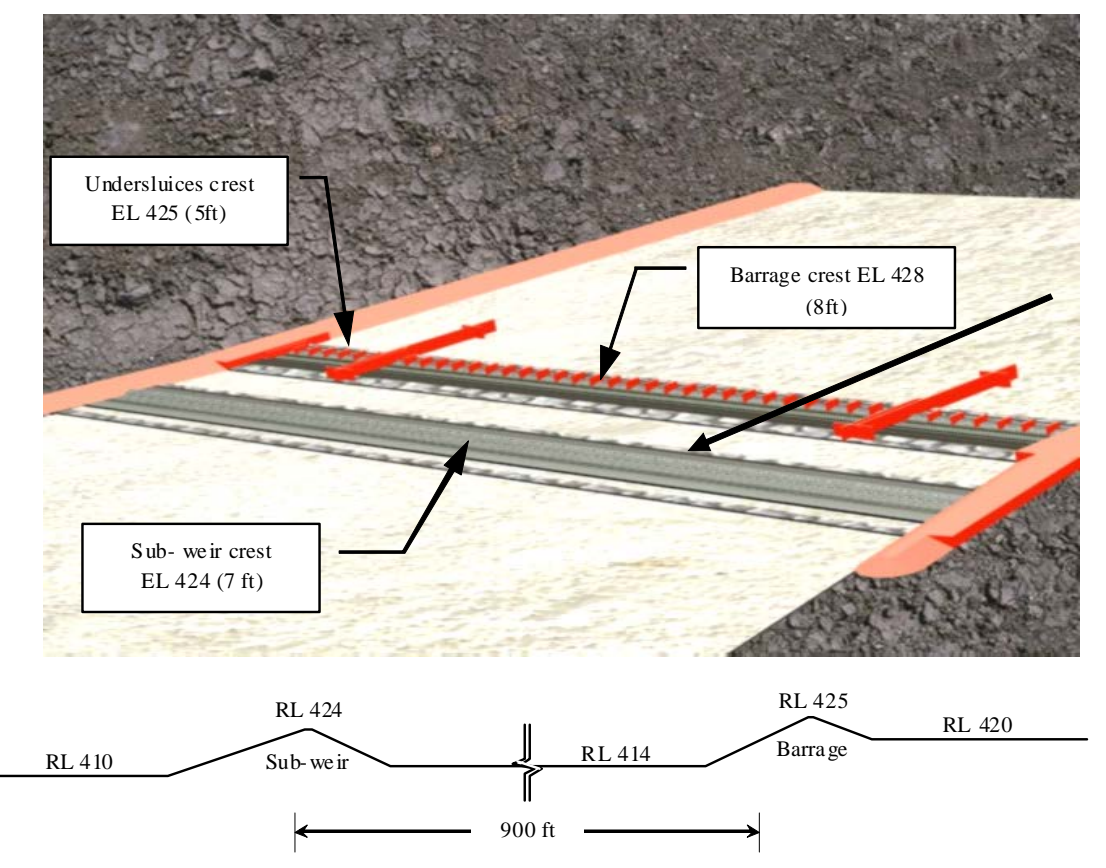

Fig. 1: Plan and cross-sections of Taunsa barrage and the sub-weir

Presently, stone apron is completely washed away, whereas the concrete block floor filters either completely or partially disappeared. These unprecedented damages raised serious questions about the safety of this very important hydraulic structure, which is the life line of seven districts of Southern Punjab, Pakistan.

Whether the design modifications, innovations and the construction of sub-weir are responsible for these damages or the failures are due to malfunctioning of the gates. Construction of sub-weir and the substitution of baffle and friction blocks with chute clocks and sill wall required to be argued at a competitive level for better understanding and decision making in the future.

Findings and proposed solutions of feasibility study: PID (2004) identified problems and proposed the remedial measures in feasibility report, which are given as under in Table 1.

The impact and friction blocks were also replaced with chute blocks and sill wall and well tested manual system of gates operation was replaced with motorized and computerized system.

Model study recommendations: Irrigation Research Institute IRI (2005) Lahore, Pakistan developed a partial physical model of two bays in a ridged bed flume at the scale of 1: 60. The Model Study Report noted that the hydraulic Jump is formed up to 400,000 cusecs discharge but start sweeping at the discharge of 500,000 cusecs and above. The report also submitted that the replacement of
Table 1: Problems and proposed solutions by consultants

\begin{tabular}{ll}
\hline Problems & Proposed solutions \\
\hline $\begin{array}{l}\text { Retrogression of levels on the } \\
\text { down stream of barrage and } \\
\text { consequential issues }\end{array}$ & $\begin{array}{l}\text { Construction of a sub-weir } \\
\text { to raise levels tail water }\end{array}$ \\
$\begin{array}{l}\text { Repeated damages to stilling } \\
\text { basin appurtenances including } \\
\text { rupture of skin concrete and } \\
\text { leaking joints of mass concrete }\end{array}$ & $\begin{array}{l}\text { Grouting of leaking joints and } \\
\text { removal of } 2 \mathrm{ft} \text { weak concrete } \\
\text { of existing d/s floor and lay } 3 \mathrm{ft} \\
\text { thick new concrete of } 4000 \mathrm{psi} \\
\text { strength }\end{array}$ \\
\hline
\end{tabular}

impact and deflector blocks by chute blocks is helpful in reducing fluctuations in the channel lower down. It was also advised that the sill wall may be lowered by two feet and its slope may be flattened to 2: 1 to eliminate any turbulence in the channel lower down. The sill wall at the downstream floor of the barrage appears to be superfluous.

The concept of stilling basin and additional blocks is to kill linear velocity by mixing and developing highly turbulent flow over the concrete floor; whereas the opposite of this was done.

Sounding/probing (2012-14): Sounding and probing carried out by Irrigation Department noted that the stone apron has shown its sinking in the width of 79-80 ft, in the length of $3500 \mathrm{ft}$, the depth varying from 3-7 ft and on downstream of the divide wall up to $4 \mathrm{ft}$ depth, in a width of 35-50 ft. Same was verified later on by the various departmental committees; rather they submitted that the sinking of stone apron was increasing day by day. Sounding/Probing Oct, 2013 indicated that the stone 
apron in weir section of the barrage (bays \# 10-60) has been launched whereas the block floor filters for the bays \# 33-37, 47, 48 and 54-57, have been either partially or completely launched. The sounding/probing for some of the bays is given in Table 2. The points B, C, D and E were taken at equal distance over the block floor whereas the $\mathrm{F}, \mathrm{G}$ and $\mathrm{H}$ were taken over the stone apron.

Findings and remedial measures proposed by technical committee: The Punjab Irrigation Department appointed a Technical Committee to diagnose reasons for the settled stone apron/block floor filters downstream of the barrage main weir and to recommend viable remedial measures.

Reasons for the damage till October, 2012: Technical Committee noted that "the sounding/probing data (October, 2012) showed scooping of stone apron ranging 3-6 ft in front of most of the weir bays as compared to the observations made during October, 2011. Sequel of construction of sub-weir like phenomenon is not hydraulically possible under normal flow conditions. The quantum of damage to stone apron necessitated a thorough review of operation of the barrage during period between October, 2011-12.

The Committee found that discharge intensities were exceeded permissible limits many times during this period but the worse cases were for the periods from June 5, 2012 to June 22, 2012 and July 18, 2012 to July 25, 2012, when the discharge intensity was exceeded from 1.62-3.5 time above the permissible limit through the gates \# 28-58. It was analyzed that during this period the intensity should be $26 \mathrm{cusec} / \mathrm{ft}$ because the existing tail water level was RL 428 (11 ft depth). But the actual intensity was about 3.5 times higher than the permissible limits.

In this situation the jump could only be contained at the Toe of glacis if the tail water level would be at RL 433 (16 ft), eventually the hydraulic jump moved downstream about $286 \mathrm{ft}$ which caused deep scour downstream of the barrage. Velocity of flow over the stone apron was $25 \mathrm{ft} / \mathrm{sec}$ which was 2.5 times more than the velocity for which the stone apron was designed.

$\underline{\text { Table 2: Sounding/probing data (ft) for some of the bays }}$

\begin{tabular}{|c|c|c|c|c|c|c|c|c|c|}
\hline \multirow[b]{2}{*}{ Bay No. } & \multirow[b]{2}{*}{ Month } & \multirow[b]{2}{*}{ Year } & \multicolumn{7}{|c|}{ Location } \\
\hline & & & B & C & $\mathrm{D}$ & $E$ & $\mathrm{~F}$ & $\mathrm{G}$ & $\mathrm{H}$ \\
\hline \multirow[t]{2}{*}{54} & October & 2012 & 0 & 0 & 0 & 1 & 5 & 4 & 3 \\
\hline & November & 2013 & 3 & 5 & 6 & 4 & 7 & -1 & -2 \\
\hline \multirow[t]{2}{*}{55} & October & 2012 & 0 & 0 & 0 & 1 & 4 & 3 & 2 \\
\hline & November & 2013 & 5 & 7 & 11 & 16 & 17 & 17 & 19 \\
\hline \multirow[t]{2}{*}{56} & October & 2012 & 0 & 0 & 0 & 1 & 5 & 3 & 2 \\
\hline & November & 2013 & 5 & 11 & 15 & 17 & 18 & 19 & 20 \\
\hline \multirow[t]{2}{*}{58} & October & 2012 & 0 & 0 & 0 & 1 & 2 & 3 & 2 \\
\hline & November & 2013 & 0 & 3 & 2 & 3 & 17 & 12 & 16 \\
\hline \multirow[t]{2}{*}{34} & October & 2012 & 0 & 0 & 0 & 1 & 6 & 6 & 5 \\
\hline & November & 2013 & 0 & 2 & 7 & 9 & 13 & 11 & 11 \\
\hline \multirow[t]{2}{*}{11} & October & 2012 & 0 & 0 & 0 & 1 & 6 & 6 & 4 \\
\hline & November & 2013 & 3 & 3 & 5 & 7 & 10 & 8 & 2 \\
\hline
\end{tabular}

Punjab Irrigation Department
Reasons for the damage observed in October, 2013: The situation was horrifying as the damages in bay \# 32-60 have increased especially in bay \# 54-57, where the damage to apron had aggravated causing complete damage to the stone apron along with settlement of the block floor. There was a pit of 5-8 ft deep at block floor and more than $16 \mathrm{ft}$ at stone apron in these bays. Similarly the inverted filter blocks along with stone apron were completely launched in bays \# 33-37, 44, 47 and 48 with about $10 \mathrm{ft}$ scour depth, whereas the block floor was intact in these bays.

The concerned staff told that the gate operator did not come on duty on March 24, 2013; consequently, the officer incharge made alternative arrangements for gates operation. Suddenly all gates from \# 32-61 went open to their full height due to short circuiting in the electrical system.

Due to sudden opening of the gates the pond level was depleted very quickly and the intensity of flow became six times at the start and gradually reduced to the permissible limits. It was also noted that the gates were closed from left side and moved forward to the right. As such the intensity of flow went on increasing from left to right by the closure of each gate. Maximum discharge intensity was reached on extreme right gates i.e., \# 54-57 and worst condition occurred.

Remedial measures proposed by technical committee: Some of the important remedial measures proposed by the Technical Committee are given as under:

- $\quad$ The pits at the place of inverted filter in bays 54-57 must be filled with proper filter material of specified thickness and it should be loaded with stone filled wire crates of appropriate size

- The stone apron should be replenished up to $50 \%$ length

- It is extremely necessary to modify the existing hoisting system to make manually operative besides electrical control

Rationale of diagnosis and remedial measures: Technical Committee accepted that the barrage is not safe and the situation is horrifying. The Committee noted that the reason for the damage to stone apron and block floor was the swept of jump as the gates were not opened keeping in view the tail water depth. They stressed that in future the gates should be opened keeping in view the tail water depth. However, operational staff did not agree with these findings. How the operators sitting in control room operate gates keeping in view tail water depth, especially when there is flood in the river?

Till date the pits at the place of block floor are not filled with the filter material as recommended by the Committee. The Committee has not given any time frame for the restoration of block floor/inverted filters and the stone apron. Question arises, why the hydraulic jump 
became so, sensitive with the tail water depth. It looks that the barrage at present is at the leniency of gate operators, who can cause such damage even at very low discharge? If the stone apron and block floor are restored, who can guaranteed that such damages will not occur again?

Discharge intensity and tail water depth: Technical Committee established that high flow intensity passed through barrage at low tail water depth; consequently the block floor and stone apron launched. The Committee stated that in year 2012 specific discharge of 91 cusec passed many times at the tail water depth of $11 \mathrm{ft}$, whereas, the actual depth should be $16 \mathrm{ft}$.

To establish reasoning for the damages, specific discharge and corresponding tail water depth from the year 1960-2012 were analyzed (Table 3). Data revealed that a number of times the same specific discharge passed through the barrage at different tail water depths. For example specific discharge 104 cusec (400000 cusec) passed at tail water depth varied from 14.5-18.0 ft, whereas 155 cusec (500000 cusec) passed at the tail water depth 15.2 and $15.7 \mathrm{ft}$ in year 1961, 1998, respectively. It is to be noted that the characteristics of hydraulic jump are always studied as the function of depths before and after the jump or corresponding Froude numbers, rather discussing specific discharge versus the tail water depth. It is being noted that after the construction of sub-weir the increase in tail water depth especially at higher discharges is insignificant. In year 2010 the flood of 960000 cusec passed at tail water depth of $21.1 \mathrm{ft}$ whereas the design depth as mentioned in the Feasibility Report is $24.5 \mathrm{ft}$. This also shows that the sub-weir may not have hydraulic justifications.

Rationale of stilling basin remodeling: Barrages/weirs in plane areas being low head hydraulic structures are normally provided with jump type stilling basins along with baffle and friction blocks as auxiliary devices to stabilize and reduce the length of the hydraulic jump/stilling basin. Most of the barrages in India, Pakistan and elsewhere in the world are provided with similar energy dissipaters, which are functioning well. The Taunsa barrage was also designed on the same hydraulic concept, however in year 2005-2008, the baffle and friction blocks were replaced with chute blocks and sill wall, respectively (Fig. 2). The remodeled stilling basin is in fact USBR II, which is suitable for high head spillways and is not appropriate for low head structures.

Table 3: Discharge intensity and tail water depth variations since the barrage in operation

\begin{tabular}{|c|c|c|c|c|c|c|c|c|c|}
\hline \multirow{3}{*}{$\frac{\text { Discharge (cusecs)/intensity }}{200000 / 52}$} & \multicolumn{9}{|c|}{ Tail water depth (ft/year) } \\
\hline & --- & --- & --- & ---- & ---- & 13.2 & 12.8 & 13.0 & 13.0 \\
\hline & & & & & 2000 & 2004 & 2011 & 2012 & \\
\hline \multirow[t]{2}{*}{$300000 / 78$} & 16.0 & & & 17.6 & 16.4 & 14.9 & 15.0 & 14.9 & \\
\hline & 1962 & ---- & ---- & 1985 & 1987 & 2001 & 2002 & 2008 & ---- \\
\hline \multirow[t]{2}{*}{$400000 / 104$} & 16.0 & 16.4 & 16.5 & 15.1 & 14.5 & 18.0 & 16.3 & 16.5 & 15.5 \\
\hline & 1963 & 1965 & 1968 & 1976 & 1972 & 1974 & 1982 & 2005 & 2010 \\
\hline \multirow[t]{2}{*}{$500000 / 129$} & 15.2 & 16.6 & 16.4 & 18.0 & 19.0 & 16.0 & 15.2 & & 15.9 \\
\hline & 1961 & 1964 & 1975 & 1977 & 1986 & 1997 & 1998 & -.-- & 2010 \\
\hline \multirow[t]{2}{*}{$600000 / 155$} & 17.0 & & & & 19.0 & 20.8 & 15.7 & 16.7 & 19.4 \\
\hline & 1973 & ---- & ---- & ---- & 1989 & 1994 & 1995 & 2006 & 2010 \\
\hline \multirow[t]{2}{*}{$700000 / 181$} & ---- & ---- & ---- & ---- & 15.0 & 19.0 & & & 20.2 \\
\hline & & & & 1976 & 1992 & ---- & ---- & 2010 & \\
\hline $960000 / 248$ & ---- & ---- & ---- & ---- & ---- & --- & ---- & ---- & $\begin{array}{l}21.1 \\
2010\end{array}$ \\
\hline
\end{tabular}

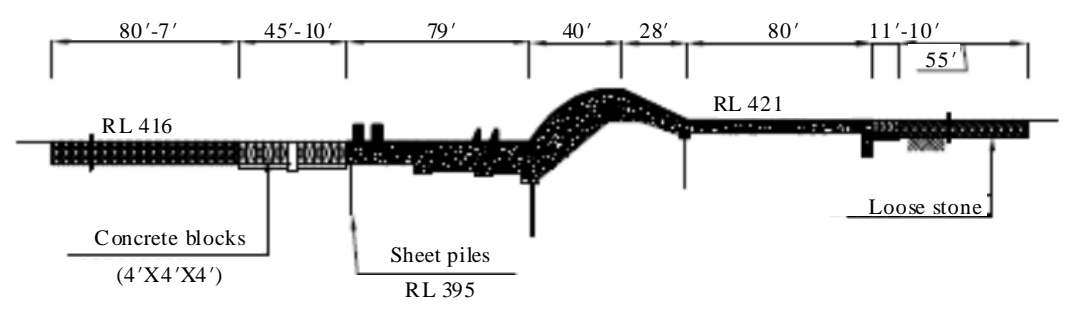

Taunsa barrage weir section

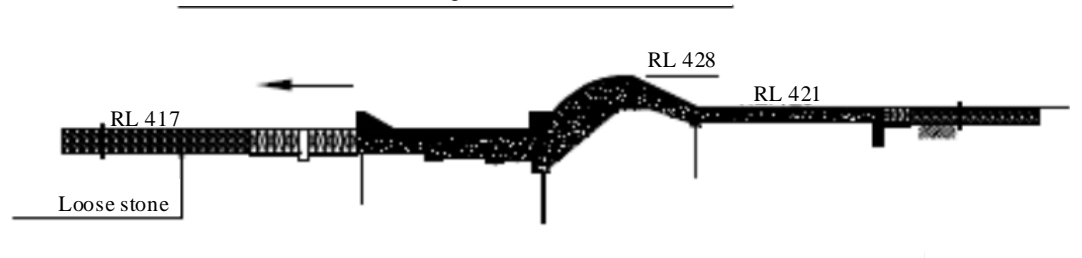

Remodeled taunsa barrage weir section

Fig. 2: Taunsa barrage stilling basins before and after rehabilitations 

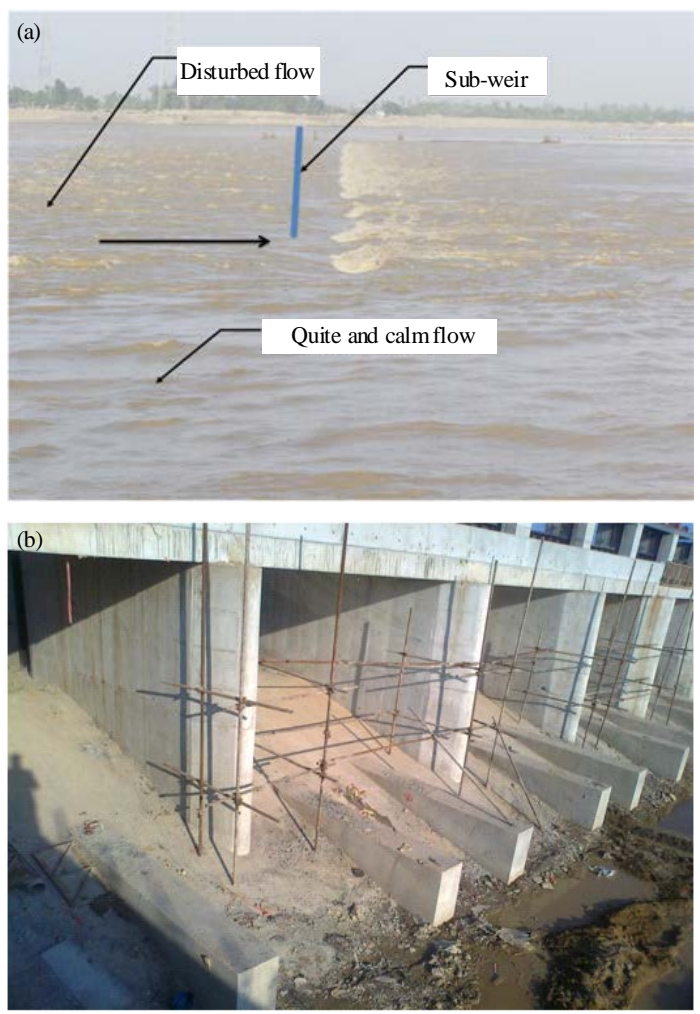

Fig. 3(a-b): (a) Flow characteristics downstream of the Taunsa barrage and (b) Chutes with chute blocks at recently constructed head regulator on LBDC canal
The stilling basins are seldom designed to confine the entire length of the hydraulic jump on paved floor, firstly for economic reasons and secondly there are means to reduce the length of the jump and to stabilize it even if tail water depth becomes less. The rationale of Taunsa Barrage stilling basin remodeling may be debated at intellectual forums, before the block floor filters and stone apron are to be restored. There is every possibility that such damages may occur again if stilling basin is not restored to original design. It is being noted that soon after the remodeling of Taunsa barrage, the hydraulic experts raised their concerns.

The flow characteristics of Taunsa barrage are shown in Fig. 3a and b. The similar basins have also been provided on the falls of Lower Bari Doab Canal (LBDC), while it's remodeling (Fig. 3b). Water flowing over the chutes may pass through the basin without developing jump and energy dissipation. These high velocity currents may have developed gullies through stone apron and block floor and subsequently entire block floor and stone apron launched/disappeared at the Taunsa barrage (Fig. 3a).

Unprecedented drifting of river: The river downstream of the barrage has changed its route by about $2.5 \mathrm{~km}$ towards Kot Addu (Fig. 4), which is endangering the city of Kot Addu. The river is just $700 \mathrm{ft}$ away from the Mugussan Canal which is final defense line for the city. The drifting of river started after the construction of sub-weir in year 2008 and is still continuing. It is being noted that the sub-weir is developing uniform flow on its downstream and flow regulation by gates diminished.
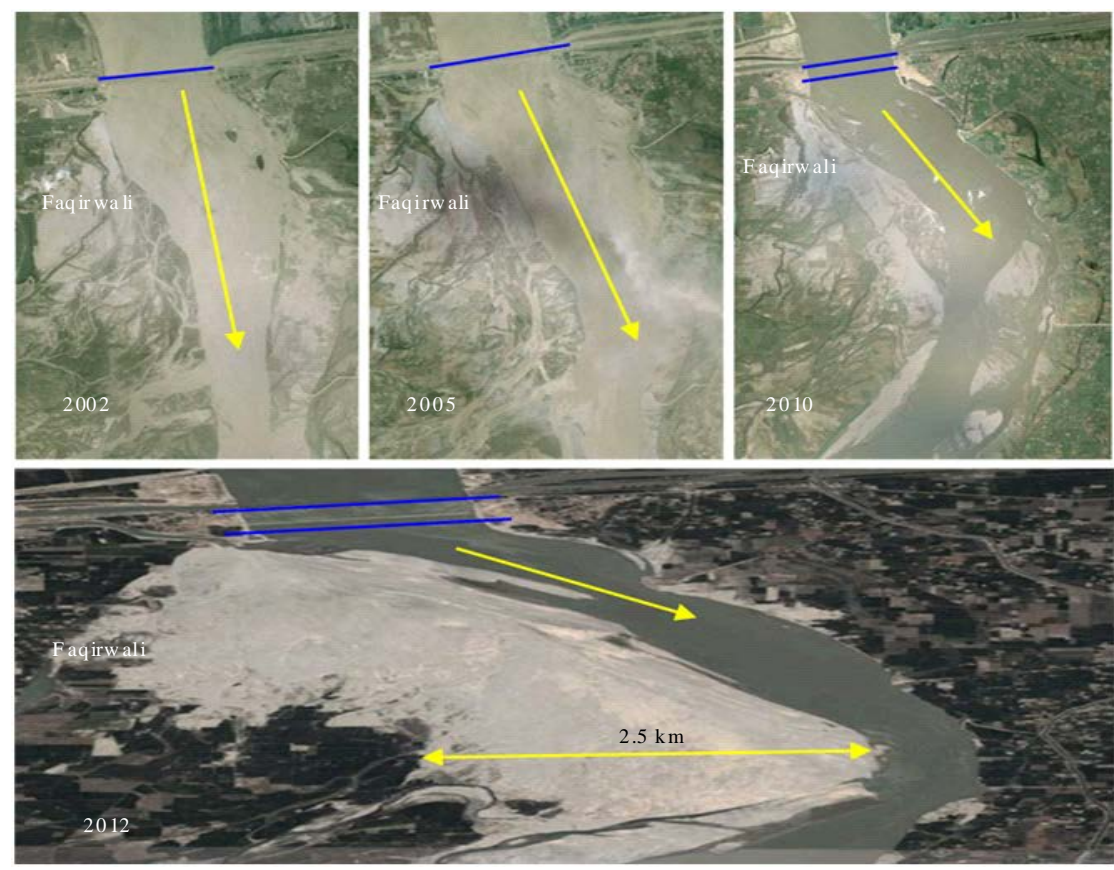

Fig. 4: Indus river drifting downstream of Taunsa barrage 


\section{CONCLUSION}

This research works emphasized that the changes made in the stilling basin may not be rational and are responsible for the launching of stone apron and block floor along with inverted filters. The situation is horrifying; need immediate measures to restore stilling basin at its original design, block floor along with inverted filters and the stone apron. Moreover the sub-weir being another hydraulic structure is responsible for the drifting of flow towards left side of the barrage.

\section{REFERENCES}

Chaudhary, Z.A., 2009a. Hydraulic/structural deficiencies at the Taunsa Barrage. Pak. J. Sci., 61: 135-140.

Chaudhary, Z.A., 2009b. Punjab barrages, hydraulic deficiencies and rehabilitation solutions. Pak. J. Water Resour., 13: 29-36.
Chaudhary, A.Z., 2010a. The Jinnah Barrage rehabilitation project-prospects and concerns. J. Dam Eng., Vol. 19, No. 3.

Chaudhary, Z.A., 2010b. Surface flow hydraulics of Taunsa barrage: Before and after rehabilitation. Pak. J. Sci. Tech., 62: 116-119.

IRI., 2005. Punjab barrages rehabilitation project: Sectional model study of Taunsa Barrage 1172. Irrigation Research Institute (IRI), Irrigation.

PID., 2004. Taunsa Barrage emergency rehabilitation and modernization project. Punjab Irrigation Department (PID), Feasibility Report, National Development Consultants to Punjab Irrigation Department.

PID., 2007. Taunsa barrage emergency rehabilitation and modernization project. Irrigation Department (PID), Design Report, National Development Consultants to Punjab Irrigation Department. 